\title{
Social responsibility in the rural businesses of the North-West Province of South Africa: coerced or business-driven?
}

\author{
Solly Matshonisa Seeletse ${ }^{1 *}$ and Mmboswobeni Watson Ladzani ${ }^{2}$ \\ ${ }^{1}$ Department of Statistics and Operations Research, University of Limpopo (Medunsa Campus), Pretoria, South Africa. \\ ${ }^{2}$ Department of Business Management, University of South Africa, Pretoria, South Africa.
}

Accepted 28 September, 2012

\begin{abstract}
Social responsibility and rural businesses seem to be unaligned in the North-West Province of South Africa. This paper establishes how rural businesses in the study area apply social responsibility issues in business. The rationale is to show the importance of incorporating social responsibility components to rural businesses to enhance their sustainability. This study used a mixed methods approach in which quantitative research dealt with numerical accounts and qualitative research was involved with non-numeric descriptions. The research tool was a questionnaire. Closed-ended and open-ended questions were used to ensure that the responses address the study needs. A total of 107 willing businesses were investigated. Tables and graphs were used quantitative data while themes were formed in the qualitative section. Empirical findings show that these rural businesses tend to perform in large proportions with regards to social responsibility activities that are compulsory to retain their business licenses. They show a tendency to ignore, or do little on the optional social responsibility activities. It is recommended that these rural businesses should embark on all social responsibility activities without neglecting others. They should make social responsibility part of their strategic mission. They lack conscience of social responsibility. In their activities, they aim to comply with the laws for licenses. This study intends to make them aware that they have started to embark on social responsibility by pointing out the activities they do, and then encourage them to increase by including the ones that they have not been doing in large scale.
\end{abstract}

Key words: Rural businesses, social responsibility, North-West Province of South Africa, poor management, small and medium-sized enterprises (SMEs).

\section{INTRODUCTION}

In South Africa, business social responsibility (BSR) is a relatively new concept. BSR is primarily the charitable benefits that businesses contribute to communities. Social responsibility never really occurred until after the year 1994, the year of the first democratic government. The 1994 government produced nine provinces for South Africa: Eastern Cape, Free State, Gauteng, KwaZuluNatal, Limpopo, Mpumalanga, North-West, Northern Cape, and the Western Cape. Each province has its own dynamics, but Gauteng and the Western Cape are more urban and more advanced. All others are mostly rural and

${ }^{*}$ Corresponding author. Email: solly.seeletse@ul.ac.za less developed in business and other economic aspects.

Social responsibility has not reached rural South Africa's businesses to the extent it has reached the urban ones. The rural provinces' businesses are thus left far behind as far as social responsibility is concerned. The rural North-West Province is next to the urban and richest Gauteng Province. Since Gauteng is South Africa's leading province in BSR, interest was to determine how the businesses of the neighbouring North-West Province are doing with regards to social responsibility as they seemed to be lagging behind.

The study intends to discuss the conduct of rural businesses with regards to social responsibility in the North-West Province. Business in the province is regulated by the Department of Economics Development, 
known as Economics Department. The province is the fourth poorest province in the country (ETU, 2011). It is $65 \%$ rural. This makes rural businesses much more in number than the urban ones, and most of them are small businesses. Social responsibility in this province is slightly visible, discretely though, and in very small proportions. This study wants to explore more about the way social responsibility occurs in the rural businesses of this province.

Social responsibility is usually associated with big business, hence the term: corporate social responsibility. Big businesses are however, mostly found in urban areas. This is evidenced by many rural-urban migrations of skilled and unskilled people in search of a better life (Kroon, 1998: 36). The migration of people from rural areas seems to have a negative effect on rural businesses. Apart from poor infrastructure in many rural areas, this 'brain drain' seems to also contribute to high failure rate of rural businesses.

Poor management also contributes to business failure rate, especially amongst small and medium enterprises (SMEs) in South Africa. Poor management accounted for $90 \%$ of these failure rates management incompetence $(40 \%)$, lack of leadership (30\%) and lack of managerial experience $(20 \%)$. Only $10 \%$ of the failure rate is due to lack of industry experience management (Badenhorst et al., 2006: 120). The problems of unemployment, poverty, illiteracy and crime rate in the North-West Province could partly be addressed through reducing rural business failure rate and strengthening management performance of these businesses. Effective management positively contribute to the improvement of performance of SMEs and consequently reduce such high failure rates (Badenhorst et al., 2006: 120).

An aspect of management that is mostly neglected in developing and growing strong and flourishing SMEs is the social responsibility of the business. Rural businesses seem to think that this aspect should be carried out by big businesses and those businesses that are in urban areas. Another aspect that also misleads rural businesses is the tendency to think of 'making money' than providing acceptable service. Hence, as most of these businesses are geographical monopolies, they have tendencies to raise prices and abusing customers. They fail to realise that in general, a business that focuses only on making money than taking care of the customer needs is a poor kind of business (CSI, 2006: 5).

The North-West Province of South Africa has an estimated population of 3.2 million people with some $65 \%$ of the population living in rural areas. The unemployment rate is at $28.0 \%$ (Stats SA, 2010). About $35 \%$ of the population in the province is illiterate and more than $60 \%$ are living below the poverty line (Stats SA, 2000: 5; National Development Agency, 2011: 1). The result of such high unemployment, illiteracy rate and people living below the poverty line are amongst others, social ills and crime rates.
Most businesses in the North-West Province have not yet abundantly seen the need to also incorporate social responsibility concept in their operations. This is mainly due to most of them being less exposed to social responsibility and also being monopolies in their areas. They are also not aware that BSR benefits may include the growth and sustainability of their enterprises, and can also add value to their local communities that use their businesses. These benefits range from job creation, inducing economic growth, and introducing innovations to attracting clients and employees in these communities (Lepoutre and Heene, 2006: 258).

In the rural North-West Province, job creation envisaged through businesses involved in social responsibility can help to address some of the socioeconomic problems of the area. The main of such problems in many rural areas are unemployment, poverty and crime (Dzansi, 2004: 5-6). A study conducted at Harvard University found that 'stakeholder-based' companies showed four times the growth rate and eight times the employment growth when compared to companies that are focused on shareholders only (Dzansi, 2004: 5). This is an indication that job creation is useful in reducing unemployment in communities. Perrini (2006: 307) has however, reported that small businesses' BSR has received relatively little attention and there is limited literature on small business experiences in industrialised countries and even less in developing countries. The businesses in the rural areas of the NorthWest Province could not be different from receiving such limited attention. The question that this study asks is:

"How socially responsible are the businesses in the rural areas of the North-West Province of South Africa?"

The contribution of rural businesses to social responsibility in the North-West Province is not clear, but at face value there is a doubt that it is taking place enough. The focus for this study is therefore to determine the extent of social responsibility of the businesses in the rural North-West Province.

\section{Aim and objectives}

\section{The aim of the study is two-fold:}

1. To establish how rural businesses in North-West, South Africa perform with regard to social responsibility in order to expose the gaps that exist in a modern business that excludes social responsibility issues, and

2. To demonstrate the value of incorporating social responsibility in business operations for the rural business.

\section{The objectives of the study are:}

1. To show the extent to which the rural businesses of 
North-West Province conduct themselves on specific components of social responsibility.

2. To show which components of social responsibility are coerced and which ones are business-driven.

3. To determine the reasons for the components that are doing well and those that are doing relatively poor.

\section{SOCIAL RESPONSIBILITY IN PERSPECTIVE}

Several studies (Narbaiza et al., 2009: 62; Niehm et al., 2008: 333) stated that the fact that social responsibility concept was originally formulated and applied in large enterprises led to it being considered as being labelled with the term 'corporate'. This notion led to small businesses believed that large businesses are the only ones that should be involved in social responsibility.

Large rural businesses tend to believe that large urban businesses have better opportunities and platforms to engage in BSR. They seem not to view 'corporate' in them as they claim that 'corporate' is in the city. As a result, rural business enterprises believe that BSR or CSR is to be performed only by large urban enterprises. The commonly used phrase of CSR that is emerging is BSR as this term does not discriminate between small or large businesses. This emergence is due to the pressures experienced by some small and rural businesses that realised that their survival and/or sustainability depended on being socially responsible regardless of their sizes or locations (Dzansi and Pretorius, 2009: 246).

The emergence of BSR puts pressure in all forms of organisations to deviate from exclusively focusing on making a profit to including legal, financial, environmental and social responsibility (among others) in their core business strategies. The term 'corporate', is being dropped generally in the use of the phrase in order to emphasise that social responsibility is not to be restricted to large enterprises only and to enable all organisations to adopt the concept freely.

Developments regarding social responsibility show increase around the globe since worldwide, companies and their human resource (HR) leadership are appreciating the notion and practice of social responsibility in their organizations and many of those that can do it, strategically include BSR within business goals and objectives. BSR amongst SMEs has however, received relatively little attention (Perrini, 2006: 308). This is especially true in rural business, such as in the NorthWest Province of South Africa. This setback is intensified by limited information and exposure on managing CSR in these businesses.

Numerous dynamics have led to the appreciation of stretching CSR beyond large urban businesses (McWilliams et al., 2006: 1). Firstly, the historical practice of CSR took place abundantly in large businesses in urban areas. Small urban businesses and rural ones had mostly excluded themselves from CSR. Second, orientation still persists in the CSR literature on large business and the examples show that urban businesses are the ones being implied. There is very limited research and discussions that are focused on CSR outside large businesses. Third, there is a muscular perception that rural businesses lack adequate influence or resources, experience and willingness to effectively address social issues required by CSR. Fourth, rural businesses tend to be not persuaded or encouraged to participate in social activism. In South Africa, from a historical perspective, rural business did not pay attention to demonstrate responsible behaviour. One actuality about the NorthWest Province is that most of the rural businesses are small businesses since even the ones that are considered large in rural understanding are of the same size as the small ones in urban areas. Due to this understanding, the managers in these businesses have behaved like small businesses.

In line with the earlier discussion, it is thus proper to consider social responsibility as a custom of corporate self-regulation integrated into a business model in which its policy functions. Thus, business should monitor and ensure its active compliance with the spirit of the law, ethical standards, and international norms (Branco and Rodriques, 2007: 6; Orlitzky et al., 2003: 404).

The objective of social responsibility is therefore to embrace responsibility for the company's actions and encourage a positive impact through its activities in the environment, consumers, employees, communities, legislation, stakeholders and all other members of the public sphere. Furthermore, socially responsible businesses would proactively promote the public interest by encouraging community growth and development. It should be seen as voluntarily eliminating practices that harm the public sphere, regardless of legality, implying that it is the deliberate inclusion of public interest into corporate decision-making.

This explanation of social responsibility is adopted to enable South African (rural and urban) businesses to develop an attitude of thinking of peak performance, even if they may lack resources. It requires change in the mindset and focus on the global sphere because social responsibility is a universal and not a geographical concept.

\section{CHARACTERIZATION OF SOCIAL RESPONSIBILITY}

In this area, social responsibility shall mean a business concept that refers to operating a business in a manner that accounts for the social and environmental impact created by the business (Bulemo, 2010). It is a dedication of a business to developing strategic policies that integrate responsible practices into daily business operations, monitoring their progress and controlling where necessary, and then to report on progress made 
toward implementing these practices.

Misshan (2011: 1) implied that it is essential for business to enhance its corporate governance policies as it fulfils its corporate social responsibilities. Bulemo (2010: 4) also suggested that budgets should be designed to cover social responsibility. They also suggested striving to maintain a high level of management transparency by disclosing to stakeholders the business goals and guidelines that clearly indicate management responsibility, and by sharing information on business progress toward company goals. These authors also emphasised involvement of staff and customers. They pointed out that companies need to work to continue earning the trust of the stakeholders. The approach to social responsibility, according to Jenkins (2006: 246) and Niehm et al. (2008: 333), among others, is founded on proper control and accounting, diversity in the company staff, compliance built on the high ethical standards of all employees, adoption of operating policies, being responsible for goods and services of the enterprise, being socially responsible, ensuring employee and customer safety in company premises, quality and control of your own activities and conduct. Hence, in unpacking social responsibility, it can be broken down into common policies made up of the following items, which are also probed in this study and presented in Table 1 as:

1. An embracing/adoption of internal controls reform.

2. A commitment to miscellany/diversity in hiring employees and barring discrimination.

3. Formation of management teams that view employees as assets rather than costs.

4. Establishment of high performance workplaces that integrate the views of line employees into decisionmaking processes.

5. Acceptance of operating policies that exceed compliance with social and environmental laws.

6. Advanced resource productivity, focused on the use of natural resources in a more productive, efficient and profitable fashion.

7. Taking responsibility for conditions under which goods are produced directly or by contract employees.

Many employees view CSR work as charity, compassion, or an allocation of resources that could better be donated by shareowners themselves. However, aggressive CSR is a vital investment in the future of a business, which is indispensable to top-line and bottom-line business success.

Early CSR reports often focused on patronage as the main enhancer of CSR (Niehm et al., 2008: 332). That notion has been displaced by a broad commitment to protecting and improving the lives of workers and the communities in which companies perform business. CSR reports currently typically address issues impacting virtually every area of operations. These include governance and ethics, worker hiring, opportunity and training, responsible purchasing and supply chain policies, and energy and environmental impact.

\section{BUSINESS SUSTAINABILITY THROUGH SOCIAL RESPONSIBILITY}

Current trends show that social responsibility of business help the businesses to have a grip on their markets, to understand and appreciate them better, and to create a platform for thriving and long terms survival, resulting in business sustainability. Emphasis on social environmental and economic sustainability has become a focus of many CSR efforts (Geldenhuys, 2009: 214; Narbaiza et al., 2009: 61; Dovers and Handmer, 1995).

Sustainability of a business implies meeting the needs of the present employees, management and customer markets (among others) without compromising the ability of future ones to meet their needs. Companies that embrace the CSR concept face challenges by stakeholders (such as customers, employees, investors and business activists) to develop a plan for the ways these businesses would use to sustain their economic prosperity while taking care of their employees and the environment. At the same time, normal investors face the challenge to ensure that they review CSR issues when analyzing companies. CSR aligned companies tend to integrate environmental, social and governance issues into their investment decision-making and ownership practices. CSR therefore, requires integrating environment, social and governance considerations into an investment analysis so as to more reliably predict financial performance. This is clearly permissible and is arguably required in all business spheres.

There are, however, still CSR issues outstanding to this date. For example, despite progress made by many companies, adoption of CSR policies and reporting are still in its early stages at most corporations. Many CSR aligned companies still need to adopt forceful social and environmental policies.

\section{SMALL BUSINESS CONTRIBUTIONS TO ADVANCE GLOBAL ECONOMIES}

Large businesses of South Africa are the ones who tend to sometimes engage in social responsibility, but generally not small businesses (AICC, 2002; Fig, 2005: 602; Fourie and Eloff, 2005: 43; Visser, 2005: 35). Since urban businesses are the ones that tend to be large while rural businesses are small businesses, social responsibility does not occur often in rural businesses. The provinces of Eastern Cape, Free State, Limpopo, Mpumalanga, Northern Cape, and the North West are mainly rural and consist of many rural businesses which are also small. Hence, social responsibility is believed to 
Table 1. Participation in social responsibility components.

\begin{tabular}{lcccc}
\hline & Agree strongly & Agree & Disagree & Disagree strongly \\
\hline Adopt internal controls for accounting purposes & 15 & 27 & 11 & 16 \\
Ensure diversity when hiring employees & 11 & 17 & 19 & 22 \\
Forbid discrimination during hiring & 12 & 14 & 18 & 25 \\
Include employees in decision making processes & 0 & 5 & 24 & 40 \\
Adopt operating policies for compliance with legislation & 2 & 61 & 5 & 1 \\
Take responsibility of goods/services of company & 39 & 16 & 14 & 0 \\
Involved in charitable activities & 3 & 1 & 31 & 34 \\
Subscribe to policy of employee safety and security & 35 & 29 & 3 & 2 \\
Ensure customer environment of safety and security & 39 & 27 & 3 & 0 \\
Ensure quality (in services and goods to customers) & 42 & 27 & 0 & 0 \\
Monitor and control activities most of the time & 18 & 6 & 23 & 22 \\
\hline
\end{tabular}

be scarce is these provinces. On the other hand, the provinces of Gauteng, KwaZulu-Natal and Western Cape seem to be having a larger number of urban areas and more urban businesses that are also large. Many of these are believed to be involved in social responsibility. Thus, North-West is among South African provinces that seem not to be practicing social responsibility adequately in their businesses.

Small businesses have driven leading economies to advanced development, and continue to help in the development of developing economies. Vietnam, Indonesia, Thailand, Singapore and Malaysia, among other countries, have reached their level of development mainly from the contributions made by the small businesses (Visagie, 1997). Geldenhuys (2009: 201) states that approximately $50 \%$ of productive employment emanates from small businesses. These small businesses are reported to contribute between 30 and $60 \%$ of the gross domestic product (GDP). China and Japan are also known to have used small businesses successfully in their development. In the USA and Canada small businesses have contributed significantly towards new job creation, resulting in employment growth (Dzansi, 2004: 58).

About half of European small businesses are involved, in some way or another, in external social responsibility causes (Perrini, 2006: 309). There is a limited degree of commitment amongst the majority of small businesses to 'formalise' social responsibility in Italy. Only $5 \%$ of small businesses in Latin America remained ideal with respect to internal small businesses social responsibility (SBSR), while inactivity with regard to external stakeholders and the environment was much higher, at 39 and 52\% respectively (Lepoutre and Heene, 2006).

Global values in the business environment promote social responsibility for various reasons. Two of these reasons are marketing and sustainability. When businesses contribute money to the wellbeing of their communities, they are not only promoting themselves but also attracting potential customers to their businesses. Given the importance of the small business sector, social responsibility should be taken seriously, especially for the benefit of growing this sector in developing economies such as the South African economy.

In most African countries, similarly, the small businesses are widely acknowledged as major contributors to national economies (Dzansi, 2004: 54-56).

In South Africa, generally, the advances in BSR have not been impressive over the years. In fact, the BSR of South African small businesses can easily be adjudged unsatisfactory. South Africa small businesses often view BSR as an unnecessary burden for them. Especially in rural areas, small businesses experience difficulties in attaining access to finance, they lack time due to being far away from resources, they have limited or no expertise and they are burdened with associated additional administrative activities that create a barrier to launching any programmes that do not contribute directly to their core functions (Geldenhuys, 2009: 211). According to Raynard and Forstater (2002: 6), efforts of small businesses that started with CSR projects receive neither recognition nor market rewards. The Codes of Good Practice of black economic empowerment further exclude small businesses from receiving any rewards for participating in BSR activities. Only corporate businesses receive recognition of their involvement scores and small businesses do not. This means that rural businesses would also not receive recognition.

Rural small businesses of South Africa lacked BSR exposure. As a result they have remained non-committed to BSR involvement for many years. Visagie (1997: 666) has reported that individual managers and the small businesses in which they work are often impartial on social change even though they cannot afford to be. There is ample pressure to direct their businesses towards social responsibility. Factors such as competetiveness and growth require a supportive social and political climate. The policy implications of an environment characterised by heightened uncertainty, economic stagnation and political upheaval create profound challenges. Economic growth and the creation of employment require a climate of confidence, hope and 
steady economic progress. Poverty levels are generally high. In some instances the high level of crime requires urgent massive attention. Small businesses have a vital role to play in all of these. Societal changes have become commonplace, but the uncertainty and lack of direction accompanying such change is problematic for small businesses. Strategic and visionary leadership is necessary in order to bring change towards social responsibility. Presently, the rural businesses in the North-West Province are not indicative of the inclination to BSR.

There are community expectations for small businesses all over the world, most of which are common. Like many countries, South Africa's small business sector is expected to contribute to poverty alleviation, employment creation and international competitiveness (Berry et al., 2002: 1). These are complementary policy objectives. Constraints in reaching these are however, existent. For example, the policy instruments introduced to meet these objectives of South African small businesses are different, ranging from literacy training to technological advice. It has become highly crucial to determine clear priority groups in the targeting of more efficient promotion activities towards the more productive small businesses. There are some complexities or difficulties though, in confronting policy makers at political or regulatory level. One of them is how best to develop an approach to small businesses that would realize a satisfactory scale of co-ordination between supply-side effort and demand potential. There is the risk of investing resources in improving supply potential where demand constraints are high. The question arises as to whether supply-side incentives have frequently been ineffective because of such demand problems or whether ambiguous supply policies and deficient service delivery are the real causes of lack of success. Ultimately, however, it is the generation of detailed information about the functioning and working of the small businesses sector that decides, first and foremost, the success or failure of a redesigned small businesses policy framework. Consequently, South African small businesses are not productive enough in terms of BSR. Moreover, policies are deficient and there is a lack of political will to design useful policy and to ensure desirable practice.

\section{RESEARCH APPROACH}

A combination of quantitative and qualitative approaches was used in this study. A quantitative research design requires numerical accounts of the responses while the qualitative research entails non-numeric descriptions of the phenomenon being investigated (Hofstee, 2006: 124-126; Neuman, 2006: 33-35). Numeric would also describe the answers required in the case of quantitative research. For qualitative study, explanations are of importance as they explain issues. Data analysis consisted of tables and graphs on the quantitative section and thematic approach on the qualitative section. Different components of social responsibility were investigated and comparison of the extent of the levels at which the North-West Province rural businesses have incorporated them was also done.

Generally, a research that combines these methods is more robust because it retains the strengths of each method while weaknesses of either method are offset by the other. The study needed a quantitative component because it was evaluating social responsibility. Evaluation is easier to comprehend when measures explaining it are more definite, which occurs when given in numeric form. The study needed to measure the extent to which rural businesses of the North-West Province of South Africa were incorporating social responsibility in their business operations. Qualitative account was necessary to explain issues that affected these businesses. It clarifies the contexts in which the occurrences ensue. Thus, combining quantitative and qualitative methods was to increase strength of the research and reduce any possible limitations that would weaken it.

\section{Instrument}

A questionnaire was used that consisted of questions that addressed various practices about business management. Among these questions were 11 that belonged to social responsibility. This study focused only on the social responsibility items. The purpose was to determine the extent to which the rural businesses in the province were socially responsible and how the businesses of the socially responsible ones performed when compared to those that were not identifiable as being socially responsible.

\section{Sample and responses}

Details of registered businesses were obtained from registers of businesses in municipalities of the North-West Province. The registers were however, outdated. Some businesses that were visited were no longer in operation while there were new ones that had emerged, which were not registered. The decision was to exclude those that were not in the registers, and concentrate on the registered ones that were still in operation. Some of the managers of those businesses were unwilling to participate in the study.

Convenience sampling became the only possible sampling method available at the time. A total of 107 willing rural businesses of North-West Province were investigated. However, after studying the responses on the items probed, inconsistencies between choices of responses and elaborations in the explanations of the way the businesses conducted what they claimed they did, 38 of the respondents' results were eliminated in an attempt to reduce the bias from dishonest responses. The study used 69 respondents. Eleven items were probed among these 69 respondents, thus 759 (11 times 69 ) responses were used in the determination of subscribing to social responsibility items or not subscribing to them.

\section{FINDINGS}

The study intended to determine the way rural businesses of North-West Province of South Africa handled social responsibility items that were coerced and those that could be business-driven.

\section{Frequencies on social responsibility components}

Table 1 summarises the frequencies obtained in the various social responsibility components, which were 
completed after eliminating the ones that demonstrated inconsistencies between their own responses.

\section{Remark}

Table 9 shows that items $6,8,9$ and 10 have very high frequencies for 'Agree strongly' in addition to having overwhelming majority of responses for the 'yes' answer. This is an indication that these rural businesses generally believe that they take responsibility for goods/services of their companies (item 6), subscribe to policies of safety and security of employees and customers (items 8 and 9) and that they viewed themselves as ensuring quality of services and goods that they deliver to customers (item 10).

Table 9 shows that items 4 and 7 have very high frequencies for 'Disagree strongly' in addition to having overwhelming majority of responses for the 'no' answer. This is an indication that the rural businesses generally exclude employees in decision making (item 4), and that they can also be viewed as not being involved in charitable activities (item 7).

\section{Respondents' verbal comments}

The verbal comments in this area emerged from the qualitative version of the study. It mainly consisted of elaborations on the issues (that is, items 1 to 11) where respondents needed or wanted to clarify their answers. Only those that showed consistencies or dishonesties after analysis of the responses were used.

\section{Internal controls for accounting}

Adoption of internal control for accounting purposes became common in business when auditors from government insisted on companies being audited. It is a an issue that every business that wants to survive must follow, else any wrong doing and suspicion of wrong doing has led to closure of some companies in the past.

Also, during registering every company had to state their accountant. Failure to produce accounting work during auditing leads to legal action against companies. In the past some companies were closed as a result of lack of evidence of having done legal work according to their mandate as given in their registration details. Generally, surviving businesses strive not to anger the eyes of government by making mistakes of a legal nature.

\section{Diversity}

Diversity is not common since the businesses are small and the diversity of activities is limited. Also, the deciding factor lies on the fact that small businesses are usually family businesses. An attempt is made to accommodate unemployed family members and relatives than to look for people who could be more deserving employees. Diversity is forced upon these businesses in cases of accounting and legal matters, also on part-time basis, mainly because some families may be lacking such expertise.

\section{Forbidding discrimination}

This also is not possible in general, given that members outside families and friends are usually not accommodated in family businesses.

\section{Including employees in decision making}

Many employees cannot make useful decisions due to lack of experience. In some businesses, due to these businesses being too small, there are not many decisions to make.

\section{Adopting policies for obeying the law}

On this one the businesses try not to offend the law because during inspections, some small businesses were shut by government in the past for not obeying the law or for doing business that the company was registered to do. In some cases they were shut because they could not produce evidence that they did what they were registered to do.

\section{Taking responsibility for goods/services}

Successful or leading small businesses seem to be the ones taking responsibility for their goods and services. These include accepting returns on defective items and doing the services again where defects are shown on jobs carried out such as in construction and mechanical work. Some small businesses showed to lose business.

There are indications that such businesses were those that refused to accept returns, claiming that people should go to the manufacturers; and those that refused to redo work that was faulty in the first time. These include unfinished work when the service provider has been paid in full.

\section{Involvement in charitable activities}

Businesses that were leading seemed to be the ones that were involved in charitable activities, such as helping with schooling for children of customers and/or communities where they are involved. Those that were not doing well 
claimed that they had no disposable portion in their finances except to pay employees.

\section{Subscribing to employee safety and security policy}

This is also a legal issue which government insists should be the case. Also, close to all these businesses adhere to this policy because they may be shut if they are found to violate it.

\section{Ensuring customer safety and security}

This is also seen in the same light as the safety of employees and accounting. Without demonstrating that it occurs, their business may be shut, hence almost all business comply in fear of being closed.

\section{Quality in services/goods}

This is easily demonstrated in leading businesses while the struggling ones do not seem to ensure that there is quality. Examples are those businesses that would correct faults and those that refuse to correct faults where they occur.

\section{Monitoring and control}

Monitoring and control also occur for those companies that are doing well, while it seems to be lacking in those that do not show success.

\section{Views on engaging in social responsibility}

These rural businesses stated that social responsibility is not for them, but for urban and large businesses. They also perceived BSR as costly and time wasting. They did not know innovative ways in which they could make BSR beneficial for their companies.

\section{Financial standing of coerced vs. business driven businesses}

Many of the businesses that were coerced to engage in social responsibility were near bankrupt compared to the ones which were business-driven. As a result the coerced ones indicated that their businesses had no room for social responsibility as they were already in need of being offered benefits of BSR.

\section{Recap}

These businesses chose their comfort zones (areas where they were comfortable), and were not driven by business ideals and objectives. They performed social responsibility 'unconsciously', mainly because of the coercion they had to keep their operating licences. They did not perform social responsibility to advance their businesses.

\section{DISCUSSION}

An extract of questions for social responsibility was formed from questions in a bigger questionnaire that addressed business practices in rural business of NorthWest Province of South Africa. The respondents were asked to respond to the questions they were asked.

Issues/items 1, 5, 8 and 9 are 'force driven' because, according to the respondents, they are 'coerced' to ensure that they are fulfilled as they are licensed when they committed to the obligations in their first application. The respondents claim that they saw businesses' licenses been taken away due to not fulfilling some of these items. The other items are considered 'business' items, which were done when the business is socially responsible by choice. As a result, in addition to analysing the overall outlook of the 11 items, the 'coerced' items receive special attention in the analysis, separate from the other items, and the 'business' ones are analysed separately in order to determine the difference made by the 'coerced' items. The two categories of items are also compared.

The respondents were required to indicate if they were performing these items, how they performed each item and comment in case they wanted to elaborate on the issues. The responses to the items were thought of as 'yes' and 'no', where 'yes' is represented as 'agree strongly' and 'agree' while 'no' takes the form of 'disagree' and 'disagree strongly' to point out the extent to which the respondents judged the extent to which they did or did not perform an item.

\section{Numerical descriptions}

In order to obtain the extent to which social responsibility is performed, the total numbers of responses are aggregated. This means that the ticked items are summed and the analysis is based on the frequencies obtained.

\section{Total responses used}

A total of 759 responses (from the 69 respondents on 11 items) based on the undoubtedly honest ones were used in the analysis.

\section{Performance of social responsibility}

The responses that convinced that respondents have performed the various social responsibility tasks were to 
Table 2. Extract of coerced items.

\begin{tabular}{lcccc}
\hline & Agree strongly & Agree & Disagree & Disagree strongly \\
\hline Adopt internal controls for accounting purposes & 15 & 27 & 11 & 16 \\
Adopt operating policies for compliance with legislation & 2 & 61 & 5 & 1 \\
Subscribe to policy of employee safety and security & 35 & 29 & 3 & 2 \\
Ensure customer environment of safety and security & 39 & 27 & 3 & 0 \\
\hline
\end{tabular}

Table 3. Comparing item 1 with other coerced items.

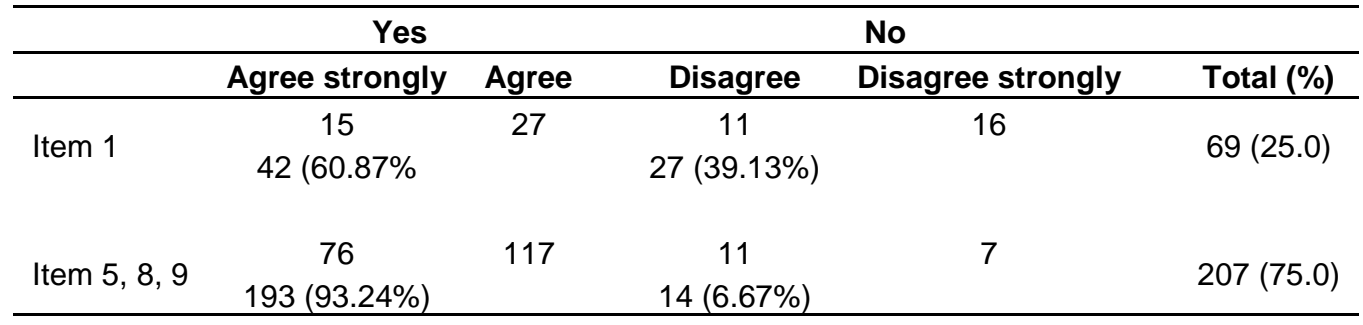

the extent of 446 out of 759 (or $58.8 \%$ ). Of these, 216 appeared under 'agreed strongly', which indicated that the performance of items were to a large extent good. The other 230 simply 'agreed', which was an indication that items were performed but not necessarily at the high extent.

\section{Non-performance of social responsibility}

The businesses that indicated to have not performed the various social responsibility tasks were 121 out of 319 (or $37.9 \%$ ). Of these, 72 stated that they disagreed strongly and the other 49 simply 'disagreed'.

\section{Coerced items}

The items which are viewed as coerced by the respondents are analysed next (Table 2) to determine the extent to which the rural businesses practiced them for their survival.

Table 2 shows that these items are performed more due to 'yes' (that is, agree strongly plus agree) for performing these items being higher than for not performing them. Since four items are at stake, the total responses are 276 (4 times 69). The total frequencies are 235 for 'yes' and are 41 for 'no'. However, item 1 is not consistent in terms of the extent to which performance of the other three items occurs. The total 'yes' extent for item 1 is $60.9 \%$ and for 'no' is $38.1 \%$. The extents for 'yes' on item 5 is $91.3 \%$, for item 8 is $92.8 \%$ and for item 9 is $95.7 \%$. The respective extends for 'no' on these items are $8.7,7.2$ and $4.3 \%$.

The summary of frequencies for item 1 and combined items 5, 8 and 9 appears in Table 3. To ease analysis regarding 'agreeing' or 'disagreeing' (together with their 'strongly' versions) with the statements given, 'yes' and 'no' are also used in Table 3. 'Yes' combines 'agree strongly' and 'agree' while 'no' combines 'disagree strongly' and 'disagree'. Frequencies are stated and the corresponding percentages appear in the bracket following each frequency. The percentages are used for comparisons. Item 1 has a total of 69 made up of 42 $(=60.9 \%)$ 'yes' and $27(=39.1 \%)$ 'no'. Other coerced items $(5,8,9)$ have a total combined frequency of 207 made of $193(=93.2 \%)$ 'yes' and $14(=6.8 \%)$ 'no'.

Moreover, item 1 has 'no' responses of close to $40 \%$. Thus, it has a considerable extent of not being performed. On the other hand, the other three items $(5,8$, and 9) are performed at a relatively high extent.

Viewed separately, item 1 has a considerable extent (close to $40 \%$ ) of 'no' responses while the three items (5, $8,9)$ have a tiny extent (below $7 \%$ ) of no responses. The combined frequencies and the corresponding percenttages on the 'yes/no' totals are displayed in Table 4.

The combined result for the items which the respondents consider to be business-driven for retaining the status or licenses of their businesses show that most respondents perform them while only a tiny minority neglect to do them.

\section{Correlation analysis of coerced items}

Correlation analysis is a statistical method to determine a linear relationship between two variables. Its values range from -1 to +1 . Negative values indicate variables that develop in different directions (that is, one increase while the other declines). Positive values indicate same 
Table 4. Summary on coerced items.

\begin{tabular}{cccc}
\hline \multicolumn{2}{c}{ Yes } & \multicolumn{2}{c}{ No } \\
\hline Agree strongly & Agree & Disagree & Disagree strongly \\
\hline 91 & 144 & 22 & 19 \\
$235(85.14 \%)$ & & $41(14.86 \%)$ \\
\hline
\end{tabular}

Table 5. Correlation matrix of coerced items.

\begin{tabular}{ccccc}
\hline Item & Item 1 & Item 5 & Item 8 & Item 9 \\
\hline 1 & 1 & & & \\
5 & 0.929034 & 1 & & \\
8 & 0.516706 & 0.441304 & 1 & \\
9 & 0.404153 & 0.33231 & 0.991942 & 1 \\
\hline
\end{tabular}

Table 6. Extract of business-driven items.

\begin{tabular}{lcccc}
\hline & Agree strongly & Agree & Disagree & Disagree strongly \\
\hline 2. Ensure diversity when hiring employees & 11 & 17 & 19 & 22 \\
3. Forbid discrimination during hiring & 12 & 14 & 18 & 25 \\
4.Include employees in decision making processes & 0 & 5 & 24 & 40 \\
6. Take responsibility of goods/services of company & 39 & 16 & 14 & 0 \\
7. Involved in charitable activities & 3 & 1 & 31 & 34 \\
10. Ensure quality (in services/goods to customers) & 42 & 27 & 0 & 0 \\
11. Monitor and control activities most of the time & 18 & 6 & 23 & 22 \\
\hline
\end{tabular}

direction. Strong relationships are indicated by values between -1 and -0.5 and between 0.5 and 1 . The value 0 indicates complete lack of a linear relationship between the variables involved. Table 5 indicates the relationships/correlation of items.

All these items have positive correlations. This gives confidence that forced items received consistent treatment by the rural practitioners. Also, items 1 and 5 have a very high correlation and items 8 and 9 have a very high correlation coefficient. This indicates that items 1 and 5 were done similarly in terms of the 'yes' and 'no' as well as their levels of being performed. The same is said about items 8 and 9 . Items 1 and 8 also have a correlation coefficient higher than 0.5 . On the other hand, other pairs show lower values of correlation coefficients. Correlation tests are conducted below based on Curwin and Slater (2002: 380). The results of tests on coerced items are displayed in Table 11 and those of businessdriven ones appear in Table 12.

\section{Correlation tests}

The steps of all the tests are the same except the test statistics values. However, all the test statistics are higher than the critical value. Therefore, in all the cases there are correlations between the pairs of items involved in the coerced items.

\section{Business-driven items}

The items which are viewed as necessary but optional by the respondents are analysed next (Table 6) to determine the extent to which the rural businesses practiced them for their survival.

\section{Remark}

Outliers are evident in items 4 (overwhelming most 'no') and item 10 (entirely 'yes'). The table shows that in the inclusion of employees in decision making (item 4); about $92.8 \%$ indicated that they did not involve employees in decision making processes of their businesses. The table also shows that of all the items, ensuring quality (item 10) was done by all the businesses. The combined frequencies of the business-driven items are displayed in Table 7.

Summarised into 'yes' and 'no' and converted into percentages result in Table 10. The total frequency for 'yes' comes from adding frequencies for 'Agree strongly' and 'Agree' (i.e. $125+86=211$ ). For 'no' it is a 
Table 7. Summary (frequencies/percentages) of business-driven items.

\begin{tabular}{lcccc}
\hline & Agree strongly & Agree & Disagree & Disagree strongly \\
\hline Frequencies & 125 & 86 & 129 & 143 \\
Percentages & 43.69 & & & 56.31 \\
\hline
\end{tabular}

Table 8. Correlation matrix of business-driven items.

\begin{tabular}{cccccccc}
\hline Item & Item 2 & Item 3 & Item 4 & Item 6 & Item 7 & Item 10 & Item 11 \\
\hline 2 & 1 & & & & & & \\
3 & 0.897291 & 1 & & & & & \\
4 & 0.901986 & 0.98677 & 1 & & & & \\
6 & -0.99165 & -0.88572 & -0.87046 & 1 & & & \\
7 & 0.798883 & 0.880337 & 0.944199 & -0.72784 & 1 & & \\
10 & -0.92705 & -0.85942 & -0.91961 & 0.871199 & -0.93895 & 1 & \\
I 11 & 0.282681 & 0.54899 & 0.632294 & -0.18574 & 0.799391 & -0.55797 & 1 \\
\hline
\end{tabular}

'Disagree' and 'Disagree strongly' (that is, $129+143=$ 272). The percentage is derived from the two sums (211 and 272 ) relative to their total of 483 .

The combined result for the items which the respondents consider to be optional in their businesses shows that most respondents fail to perform the items while fewer opt to do them.

\section{Correlation analysis of business-driven items}

The extent of agreement is checked among the businessdriven items. Table 8 presents the correlation matrix of the items (that is, variables) involved.

Negative correlations generally occur when an item requiring no cost from business is correlated with an item that requires cost. Smaller correlations (between -0.5 and 0 and between 0 and +0.5 ) indicate less dependence of variables on each other while larger ones (between -0.5 and -1 and between 0.5 and 1) imply that variables can be used to predict each other with a higher precision).

Negative correlations pairs are seen for the pairs of items:

a) Large correlations: $(2,6),(2,10),(3,6),(3,10),(4,6)$, $(4,10),(6,7),(7,10),(10,11)$

b) Small correlation: $(6,11)$

\section{Correlation tests of negative correlation pairs}

All the test statistics are higher than the critical value.
Therefore, in all the cases there are correlations between the pairs of items involved in the business-driven items that have negative correlation coefficients.

Positive correlations pairs occur for the pairs of items:

a) Large correlations: $(2,3),(2,4),(2,7)(3,4),(3,7),(3$, $11),(4,7),(4,11),(6,10),(7,11)$,

b) Small correlation: $(2,11)$

\section{Correlation tests}

Since the same data set is used, similar procedures for the correlation tests as in the coerced items follow:

\section{Correlation tests of positive correlation pairs}

In this instance as well, all the test statistics are higher than the critical value. Thus, in all the cases there are correlations between the pairs of items involved in the business-driven items that have positive correlation coefficients.

\section{Further interpretation}

Taking example of the negative correlations in pair $(2,6)$ and $(2,10)$, it shows that item 2 (ensuring diversity when hiring employees) does not have compulsory extra cost/expense to incorporate in the business while items 6 (taking responsibility for goods/services) and 10 (ensuring quality) both require extra expenses. Positive 
Table 9. Participation in social responsibility items.

\begin{tabular}{lcccc}
\hline & Agree strongly & Agree & Disagree & Disagree strongly \\
\hline Item 1 & 15 & 27 & 11 & 16 \\
Item 2 & 11 & 17 & 19 & 22 \\
Item 3 & 12 & 14 & 18 & 25 \\
Item 4 & 0 & 5 & 24 & 40 \\
Item 5 & 2 & 61 & 5 & 1 \\
Item 6 & 39 & 16 & 14 & 0 \\
Item 7 & 3 & 1 & 31 & 34 \\
Item 8 & 35 & 29 & 3 & 2 \\
Item 9 & 39 & 27 & 3 & 0 \\
Item 10 & 42 & 27 & 0 & 0 \\
Item 11 & 18 & 6 & 23 & 22 \\
Frequencies & 446 & & & 313 \\
Percentages & 58.76 & & & 41.24 \\
\hline
\end{tabular}

Table 10. Comparison of participation of coerced and business-driven items.

\begin{tabular}{lcc}
\hline & Yes & No \\
\hline Coerce items & 85.14 & 14.86 \\
Business-driven items & 43.69 & 56.31 \\
All 11 items & 58.76 & 41.24 \\
\hline
\end{tabular}

ones occur where items either both require extra expense, or both can be done with no additional cost.

\section{Comparison of coerced and business-driven items}

The combined table of frequencies of all the items (coerced and business-driven) is reproduced in the Table 9.

Recalling the findings in the previous two areas, the results for the entire group, for the forced items and for the voluntary items are brought together. Table 10 presents the results.

When all items are considered, over half (but below $60 \%$ ) of the rural business perform the social responsibility activities while just over $40 \%$ do not perform them. That, even though more of them perform them, a considerable proportion of these items are still not performed.

When the compulsory ones to be licensed are considered separately, most of these items are performed by these businesses since over $85 \%$ shows performance of the items and only below $15 \%$ shows non-performance of the items.

Voluntary items, which are the ones considered the choice of the business to do or not to do them, were done at a performance level of less than $45 \%$ while their nonperformance exceeded $55 \%$.

This shows some deliberate negligence on the part of the rural businesses since where they know they can lose business licenses; they tend to perform the activities in large scales while ignoring activities where they have no pressure to perform.

A visual display (that is, a bar chart) has also been used to emphasise these points. It shows these performance levels explained earlier (Figure 1).

A revelation is that increased performance of social responsibility activities in the rural businesses of the North-West Province of South Africa seems to have occurred because of the contribution from the performance of the coerced items among these activities.

\section{Financial performance of coerced vs. business- driven businesses}

The North-West Province rural businesses that were coerced to engage in social responsibility stated that social responsibility was not for them, but for urban and large businesses. They also perceived BSR as expensive and time wasting. They did not know innovative ways in which they could make BSR beneficial for their companies. Many of them were already near bankrupt. As a result they also stated that their businesses had no room for social responsibility as they also needed to be assisted or offered benefits of BSR. The ones that showed to be business-driven indicated to be financially stronger than the coerced into lawful BSR activities.

\section{Recap}

The rural businesses of the North-West Province of South Africa conducted social responsibility through obeying the law in fear of being terminated as businesses. In social responsibility cases where the law was not involved and business intent was necessary, 
Table 11. Correlation tests of coerced items.

\begin{tabular}{llc}
\hline Items $\mathbf{1}$ and $\mathbf{5}$ & Items 8 and 9 & \multicolumn{1}{c}{ Other pairs } \\
\hline $\begin{array}{l}\mathrm{H}_{0}: \rho_{15}=0, \mathrm{H}_{1}: \rho_{15}>0 \\
\text { Significance level } \alpha=0.05\end{array}$ & $\begin{array}{l}\mathrm{H}_{0}: \rho_{89}=0, \mathrm{H}_{1}: \rho_{89}>0 \\
\text { Significance level } \alpha=0.05\end{array}$ & $t_{18}=\frac{r \sqrt{n-2}}{\sqrt{1-r^{2}}}=\frac{0.514 \sqrt{105}}{\sqrt{1-0.514^{2}}}=6.14$ \\
$\begin{array}{l}\text { Critical value 1.66 value 1.66 } \\
\text { Test statistic: }\end{array}$ & $t=\frac{r \sqrt{n-2}}{\sqrt{1-r^{2}}}$ & $t_{19}=\frac{0.404 \sqrt{105}}{\sqrt{1-0.404^{2}}}=4.53$ \\
$t=\frac{r \sqrt{n-2}}{\sqrt{1-r^{2}}}$ & $=\frac{0.992 \sqrt{107-2}}{\sqrt{1-0.992^{2}}}$ & $t_{58}=\frac{0.441 \sqrt{105}}{\sqrt{1-0.441^{2}}}=5.03$ \\
$=\frac{0.929 \sqrt{107-2}}{\sqrt{1-0.929^{2}}}$ & $=80.23$ & $t_{59}=\frac{0.332 \sqrt{105}}{\sqrt{1-0.332^{2}}}=3.61$ \\
$=25.73$ & &
\end{tabular}

Table 12. Correlation tests of business-driven items.

\begin{tabular}{lcc}
\hline Items 2 and $\mathbf{3}$ & Other pairs of items & Other pairs \\
\hline $\mathrm{H}_{0}: \rho_{23}=0, \mathrm{H}_{1}: \rho_{23}>0$ & $t_{24}=21.41$ & \\
Significance level $\alpha=0.05$ & $t_{27}=13.61$ & \\
Critical value 1.66 & $t_{34}=62.37$ & $t_{6,10}=18.18$ \\
Test statistic: & $t_{37}=19.02$ & $t_{7,10}=13.63$ \\
$t=\frac{r \sqrt{n-2}}{\sqrt{1-r^{2}}}$ & $t_{3,11}=6.73$ & $t_{2,10}=3.02$ \\
$=\frac{0.89729 \sqrt{105}}{\sqrt{1-0.89729^{2}}}$ & $t_{47}=29.37$ & \\
$=20.83$ & $t_{4,11}=8.36$ & \\
\hline
\end{tabular}

these businesses did not bother to incorporate the social responsibility aspects involved.

\section{Conclusion}

The principal aim of this study was to determine the extent to which rural businesses in the North-West Province of South Africa conducted social responsibility. Various components of social responsibility were probed. There were those that were derived from the legalities of being licensed to perform, without which a business would not be allowed to operate. Others were social responsibility issues based on the social responsibility definition. The key study findings revealed that these businesses performed the legally connected activities to a large extent, and failed to show commitment in implementing the nonbinding social responsibility activities.

As a result of the aforementioned findings it is evident that those rural businesses did not focus on running their enterprises by embarking on business activities. Rather, their main interest seems to have been to ensure compliance with the law to avoid termination of operating licences, and thus retaining their status as businesses.

In other words, where these businesses became socially responsible, it was generally not for business purposes, but to avoid friction with the legal system. To some extent these businesses may be viewed as being deliberate in choosing some social responsibility activities and ignoring others.

\section{RECOMMENDATIONS}

\section{Recommendation for the rural businesses in the province}

These businesses were shown to perceive social responsibility as an aspect for urban large businesses. 


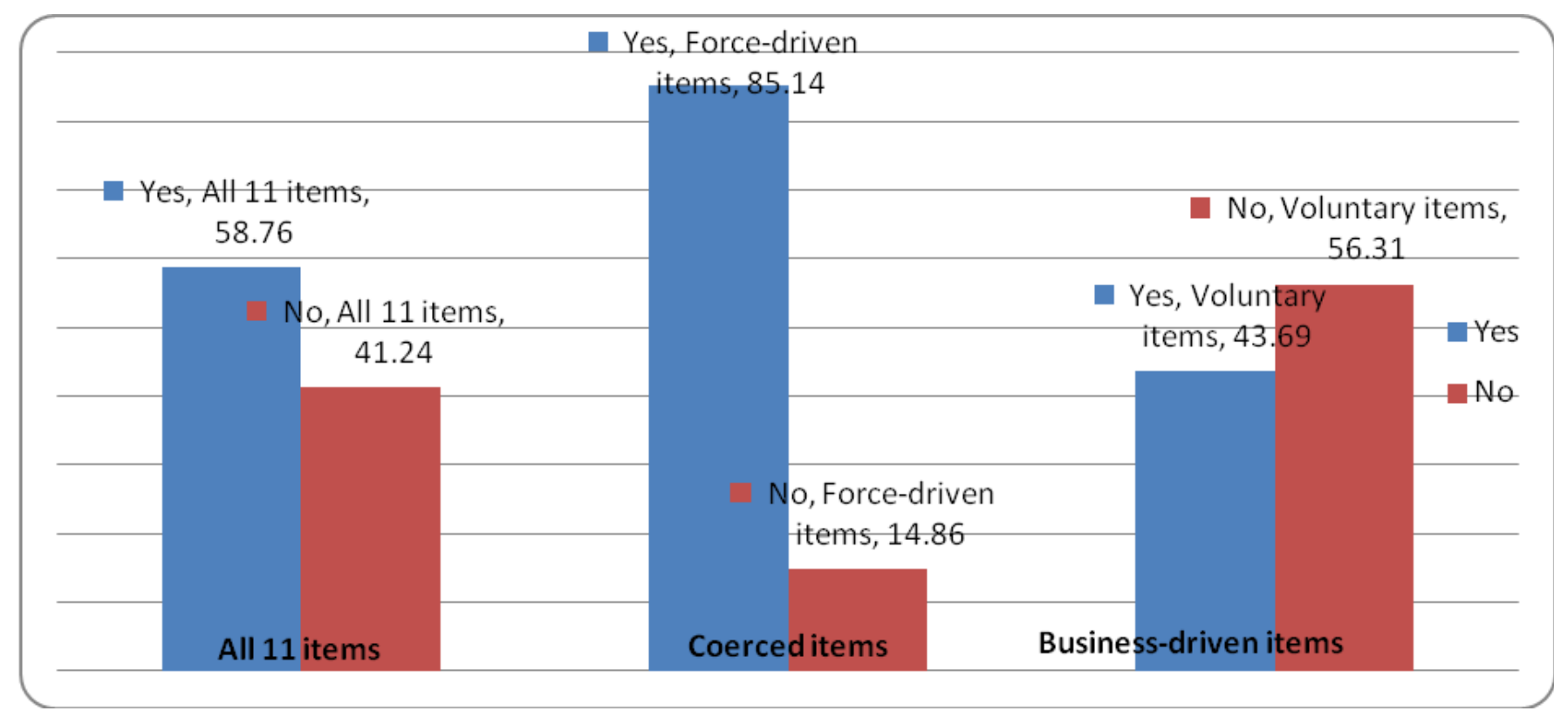

Figure 1. Levels of (non) performance of the items. Yes = items were performed; No = items were not performed.

For that reason they should be shown the potential that social responsibility has in being able to upgrade the rural business. It is therefore recommended that the rural businesses of North-West Province in South Africa should:

1. Be exposed to issues of enhanced marketing, increased revenue and profits that are possible through social responsibility.

2. Enlightened about the ultimate benefit of social responsibility business, which is business sustainability and survival.

3. Incorporate social responsibility items as if the items are all business-driven, that is, to perform all the social responsibility activities without neglecting the noncompulsory ones.

\section{Recommendations for the economics department of the province}

Since the North West Province of South Africa is the regulator and enhancer of business in the province it is recommended that it should:

Give incentives to businesses that employ members of the general public rather than those biased towards family members and friends.

Therefore, if companies give priority to family members and friends when hiring employees, then the economic planning division of the province should ensure that they do not benefit to the extent that the ones that incorporate social responsibility without bias are benefiting, such as in financial support and procurement.

\section{Study limitations}

Many urban businesses in the North-West are franchises and branches of Gauteng and operate according to rules of the ones based outside the province. They are also very large compared to the rural ones. Many of them require authorisation of head office to give data for research, and they do not easily give data or answer questions. Limited data was however obtained from few urban ones, but could not be used for any study. As a result there was no data available on urban businesses of the North-West Province for use in this study or for worthy comparison with rural counterparts. Comparison of rural businesses of other provinces was also not done because there was no available data at the same time as this one. Any attempt to find data for a similar study would have come later. There would have been a time lag as a result. Jeopardising and undermining fair comparison were the risk factors to be avoided.

\section{REFERENCES}

AICC (2002). Socially responsible investment in South Africa. Johannesburg: African Institute for Corporate Citizenship .

Badenhorst JA, Cant MC, de J Cronje GJ, Du TJS, Erasmus BJ, Grobler PA, Kruger LP, Machado R, de K Marais A, Marx J, Strydom JW, Mpofu RT (2006). Introduction to business management. $6^{\text {th }}$ edition. Johannesburg: Thomson International.

Berry A, Von Blottnitz AB, Cassim R, Kesper A, Rajaratnam B, van Seventer DE (2002). The economics of SMMEs in South Africa. Trade and Industrial Policy Strategies. 
Branco MC, Rodrigues LL (2007). Positioning stakeholder theory within the debate on corporate social responsibility. Elec. J. Bus. Ethics Org. Stud. 12:5-15.

Bulemo KB (2010). Internal control and the law: corporate social responsibility. Annual Report, Meso Consulting pp.1-24.

CSI (2006). The CSI Handbook: the state of CSI, $9^{\text {th }}$ edition. Trialogue. Kenilworth, Cape Town.

Curwin J, Slater R (2002). Quantitative methods for business decisions, $5^{\text {th }}$ edition. London: Thomson Learning.

Dovers S, Handmer J (1995). Ignorance, the precautionary principle, and sustainability. Ambio 24(2):92-97.

Dzansi DY (2004). Social responsibility of SMMEs in rural communities. Unpublished doctoral thesis. Pretoria, South Africa: University of Pretoria.

Dzansi DY, Pretorius M (2009). Addressing and measuring small business social responsibility in the African context: a stakeholder framework. Soc. Res. J. 5(2):245-256.

ETU (2011). Understanding Poverty and Development. Education and Training Unit. Available from: http://www.etu.org.za/toolbox/docs/development/poverty.html (Accessed on 24 November 2011).

Fig D (2005). Manufacturing amnesia: corporate social responsibility in South Africa. Int. Affairs 81(3):599-617.

Fourie A, Eloff $T$ (2005). The case for collective business action to achieve systems change: exploring the contributions made by the private sector to the social, economic and political transformation process in South Africa. J. Corp. Citiz. 18(Summer):39-48.

Geldenhuys J (2009). 'Corporate social responsibility in small business andmedium enterprises in South Africa' In: Aras G, Crowther, D and Vettori S (eds). 2009. Corporate social responsibility in SMEs. Research series: Issues in corporate behavior and sustainability. Social Responsibility Networks, UK.

Hofstee $E$ (2006). Constructing a good dissertation: A practical guide in finishing a Masters, MBA or PhD on Schedule. Johannesburg: EPE.

Jenkins $H$ (2006). Small business champions for corporate social responsibility. J. Bus. Ethics 67(3):241-256.

Kroon J (1998). Entrepreneurship: Start your own business. Pretoria: Kagiso.

Lepoutre J, Heene A (2006). Investigating the impact of firm size on small business social responsibility: A critical review. J. Bus. Ethics 67:257-273.
McWilliams A, Siegel DS, Wright PM (2006). Corporate social responsibility: Strategic implications. J. Man. Stud. 43(1):1-18.

Misshan P (2011). Corporate social responsibility and citizen activities. Project report no. $13^{\text {th }}$ September, presented at the Indaba Hotel, Fourways, South Africa 5:1-11.

National Development Agency (NDA) (2011). North-West Province, Background. Available from: http://www.nda.org.za/(accessed on 07 March 2011).

Narbaiza L, Ibañez A, Aragón C, Iturrioz C (2009). A proposal for measuring social responsibility activities in SMEs. In: Aras G, Crowther, D and Vettori S (eds). 2009. Corporate social responsibility in SMEs. Research series: Issues in corporate behavior and sustainability. Social Responsibility Networks, UK.

Neuman WL (2006). Social research methods: qualitative and quantitative approaches. 6th edition. Whitewater, Wisconsin: Pearson Education.

Niehm LS, Swinney J, Miller NJ (2008). Community social responsibility andits consequences for family business performance. J. Small Bus. Manag. 46(3):331-350.

Orlitzky M, Frank L, Schmidt S, Rynes L (2003). Corporate social and financial performance: a meta-analysis. Org. Stud. 24(3):403-441.

Perrini F (2006). SMEs and CSR theory: 'Evidence and implications from an Italian perspective. J. Bus. Ethics 67:305-316.

Raynard P, Forstater M (2002). Corporate social responsibility: Implications for small and medium enterprises in developing countries. United Nations Industrial Development Organization, Vienna, Austria.

Stats SA (Statistics South Africa, 2000). Statistics in brief. Pretoria: Government Printers.

Stats SA (Statistics South Africa, 2010). Labour Force Survey, Quarter 3. Pretoria: Government Printers.

Visagie JC (1997). SMMEs' challenges in reconstructing South Africa. Department of Industrial Sociology, Potchefstroom University, Potchefstroom, South Africa. Manag. Decis. 35 (9):660-667.

Visser W (2005). Corporate citizenship in South Africa: A review of progress since democracy. J. Corp. Citiz. 18(Summer):29-38. 